\title{
Colour Changes in Blanc de Noir Wines during Ageing at Different Temperatures and its Colour Preference Limits
}

\author{
L.P. ELLIS AND C. KOK \\ Viticultural and Oenological Research Institute, Private Bag X5026, 7600 Stellenbosch, Republic of South Africa.
}

Submitted for publication: January 1987

Accepted for publication: March 1987

Keywords: Blanc de noir, wine, ageing, temperature, colour

\begin{abstract}
Visual as well as spectrophotometrically measured colour changes were studied in six blanc de noir wines during ageing at $0,10,20^{\circ} \mathrm{C}$ and $30^{\circ} \mathrm{C}$. Visual colour descriptions were compared with spectrophotometric measurements of absorbance at $420 \mathrm{~nm}$ and $520 \mathrm{~nm}$, in order to obtain colour preference limits for this type of wine. A limit where the spectrophotometrically measured absorbance values at $420 \mathrm{~nm}$ and $520 \mathrm{~nm}$ do not exceed 0,200 and 0,160 respectively, was found best suited for this purpose. The results showed that the colour of blanc de noir wine is susceptible to change during ageing. This deterioration of colour quality during ageing occurred especially in wines which initially had a more intense colour. High temperatures during ageing have a detrimental effect on the retention of colour quality.
\end{abstract}

Colour is a significant factor in consumer acceptability of foods and beverages. Regardless of the degree to which colour is a true indication of the organoleptic properties of a wine, the sensory quality is directly influenced to a considerable degree by colour and it is therefore recognized as important in general quality grading. Tromp \& Van Wyk (1977) concluded that colour was one of the most important quality assessment factors amongst red wines without abnormalities. Traditionally wines have been produced to an approximate colour, determined by the individual winemaker's ability to make blends that conform to what he believes to be the correct standard for a certain type of wine. Present blends are matched to previous blends by visual comparison. Although samples used for comparison are subject to darkening, arbitrary corrections can be made to ensure a relatively constant colour acceptable to the market. With the appearance of a new product, blanc de noir (wine made entirely of free run juice from red grapes), on the South African market, the need for colour standardization arose.

The need for colour standardization amongst the important wine types has long been recognized. As early as 1885 Salleron devised a "vino-colorimetre" which was designed to determine the nuances of colour in red wines (Amerine, Ough \& Bailey, 1959). Many colour specifications are expressed in non-specific, subjective terms such as "darker-coloured", "medium red", "lighter-coloured", "deep red", etc. Due to the differences of interpretation when applying such a system, it was necessary to establish some kind of an objective analytical procedure to specify the colour of specific wine types.

Winkler \& Amerine (1938) first recognized the importance of converting spectral data to trichromatic values in reporting wine colour, while Robinson, Bertino \& Whitcombe (1967) stated that tristimulus measurements are preferable to measurements of a specific absorption band when changes in colour must be reported in terms relevant to human visual response. However, a thorough understanding of the interrelationships of the three colour dimensions and their significance in wine colour descriptions is a prerequisite to the setting of tristimulus colour specifications and tolerances. Fur- thermore, most producers are not equipped to apply this technique on a routine basis. Therefore absorbance readings at $420 \mathrm{~nm}$ and $520 \mathrm{~nm}$ are commonly used as objective measurements for studying changes in wine colour (Amerine \& Ough, 1975).

Although the colour characteristics of white, rosé and red wines have been determined (Amerine et al., 1959; Ough \& Amerine, 1967; Robinson et al., 1967; Timberlake, 1981; Piracci, 1984), no results on the colour characteristics of blanc de noir wines have yet been reported, nor were any attempts made to compare instrumental measurements with visual evaluation of colour differences.

The colour of wines is very susceptible to change during storage. Storage temperature during ageing plays an important role in this regard (Marais \& Pool, 1980; Sims \& Morris, 1984). The purpose of this work was therefore to study the colour characteristics of blanc de noir wines with specific reference to long term stability at various temperatures as well as for the setting of generally acceptable colour limits.

\section{MATERIALS AND METHODS}

Wines:

Six commercial blanc de noir wines, acquired approximately two months after bottling, were used. Analyses of the wines are given in Table 1 . The wines were stored at temperatures of $0,10,20^{\circ} \mathrm{C}$ and $30^{\circ} \mathrm{C}$ for a period of two years to study the effect of temperature and ageing on wine colour. These wines, as well as a further 60 wines, consisting of blends of red, rosé, blanc de noir and white wines, were used for the determination of blanc de noir colour preference limits.

\section{Colour measurements:}

Spectrophotometric measurements of absorbance at $420 \mathrm{~nm}$ and $520 \mathrm{~nm}$ were done monthly during the first year and again after two years of storage on a LKB Ultrospec 4050 . A $10 \mathrm{~mm}$ light path with a water reference was used.

\section{Visual colour descriptions:}

To follow the visual colour changes during ageing of the six blanc de noir wines, evaluations were done monthly by a panel of seven judges with experience of 
TABLE 1

Analysis of blanc de noir wines used in this study.

\begin{tabular}{c|l|c|c|c|c|c|c|c|c}
\hline $\begin{array}{c}\text { Wine } \\
\text { number }\end{array}$ & \multicolumn{1}{|c|}{ Cultivar } & $\begin{array}{c}\text { Alcohol } \\
\% \text { per } \\
\text { vol. }\end{array}$ & $\begin{array}{c}\text { Redu- } \\
\text { cing } \\
\text { sugar } \\
\mathrm{g} / l\end{array}$ & $\begin{array}{c}\text { Total } \\
\text { Acidity } \\
\mathrm{g} / l\end{array}$ & $\mathrm{pH}$ & $\begin{array}{c}\mathrm{SO}_{2} \\
\text { free } \\
\mathrm{mg} / l\end{array}$ & $\begin{array}{c}\mathrm{SO}_{2} \\
\text { total } \\
\mathrm{mg} / l\end{array}$ & $\begin{array}{c}\text { Absor- } \\
\text { bance } \\
420 \mathrm{~nm}\end{array}$ & $\begin{array}{c}\text { Absor- } \\
\text { bance } \\
520 \mathrm{~nm}\end{array}$ \\
\hline 1 & Pinotage & 11,55 & 2,5 & 6,0 & 3,64 & 20 & 88 & 0,116 & 0,046 \\
2 & Various (blend) & 11,95 & 14,0 & 4,9 & 3,59 & 12 & 158 & 0,090 & 0,067 \\
3 & Pinotage & 12,64 & 11,4 & 5,7 & 3,41 & 16 & 106 & 0,103 & 0,090 \\
4 & Cabernet & 11,38 & 3,5 & 5,6 & 3,17 & 21 & 51 & 0,110 & 0,094 \\
& Sauvignon & & & & & & & & \\
5 & Various (blend) & 12,32 & 20,3 & 5,2 & 3,45 & 20 & 158 & 0,174 & 0,151 \\
6 & Shiraz & 12,32 & 6,5 & 4,6 & 3,70 & 19 & 134 & 0,222 & 0,195 \\
\hline
\end{tabular}

producing these wines for commercial purposes. The sixty blended wines were analysed and evaluated once only by a panel of 16 judges. The visual colour of each wine was evaluated by using the colour evaluation card as depicted in Fig. 1. The judges had to indicate the visual colour of each wine as well as whether the colour was acceptable for a blanc de noir wine. For the purpose of this study, the judges were asked to evaluate the colour in the context of expected blanc de noir colour, e.g. a "dark red" indication for a blanc de noir wine is different from a "dark red" indication in the evaluation of red wine colour. The wines were served in tasting glasses (ISO/DIS 5494) and the evaluation was done in a specially constructed tasting room with a white background under daylight conditions.

The colour description for each wine was determined as follows: If five or more judges indicated a specific colour, this colour was accepted. If four judges indi-

\section{BLANC DE NOIR COLOUR EVALUATION}

JUDGE: . . . . . . . . .

WINE NUMBER:

DATE:

Describe the colour by marking only one of the appropiate blocks:

\begin{tabular}{|l|l|l|l|l|l|l|l|}
\hline & Grey & Yel low & Orange & Pink & Red & Purple & Brown \\
\hline Light & & & & & & & \\
\hline Medium & & & & & & & \\
\hline Dark & & & & & & & \\
\hline
\end{tabular}

Please mark the appropiate block:

Acceptable ?

Is the colour as a blanc de noir

Unacceptable ?

FIG. 1

Colour evaluation card for blanc de noir wines. 
cated "pink" and three judges indicated "orange" for a specific wine, the colour was described as "pinkorange". The colour description was further defined by using the light, medium and dark descriptive parameters. Indications of "acceptable" or "unacceptable" were obtained when five or more of the seven judges agreed on the acceptability of the colour. When three or four judges indicated either "acceptable" or "unacceptable", an indication of "unsure" was recorded. Respective indications for the 60 wines where 16 judges participated were obtained as follows: "Acceptable" or "unacceptable" - 10 or more of one indication; "unsure" - less than 10 of one indication.

\section{RESULTS AND DISCUSSION}

Visual colour descriptions versus absorbance measurements:

A plot of the visual colour (composite results of the judges using the card depicted in Fig. 1) against the absorbance readings $\left(\mathrm{A}_{420}, \mathrm{~A}_{520}\right)$ for all the wines is given in Fig. 2, with similar results deleted where overwriting occurred. It is clear that a variety of colours, ranging from very light (light yellow-grey) to relatively dark (medium red, dark pink and dark orange-brown) occurred. Since blanc de noir wines are made from red cultivars, most of the colours were light yellow to pink,

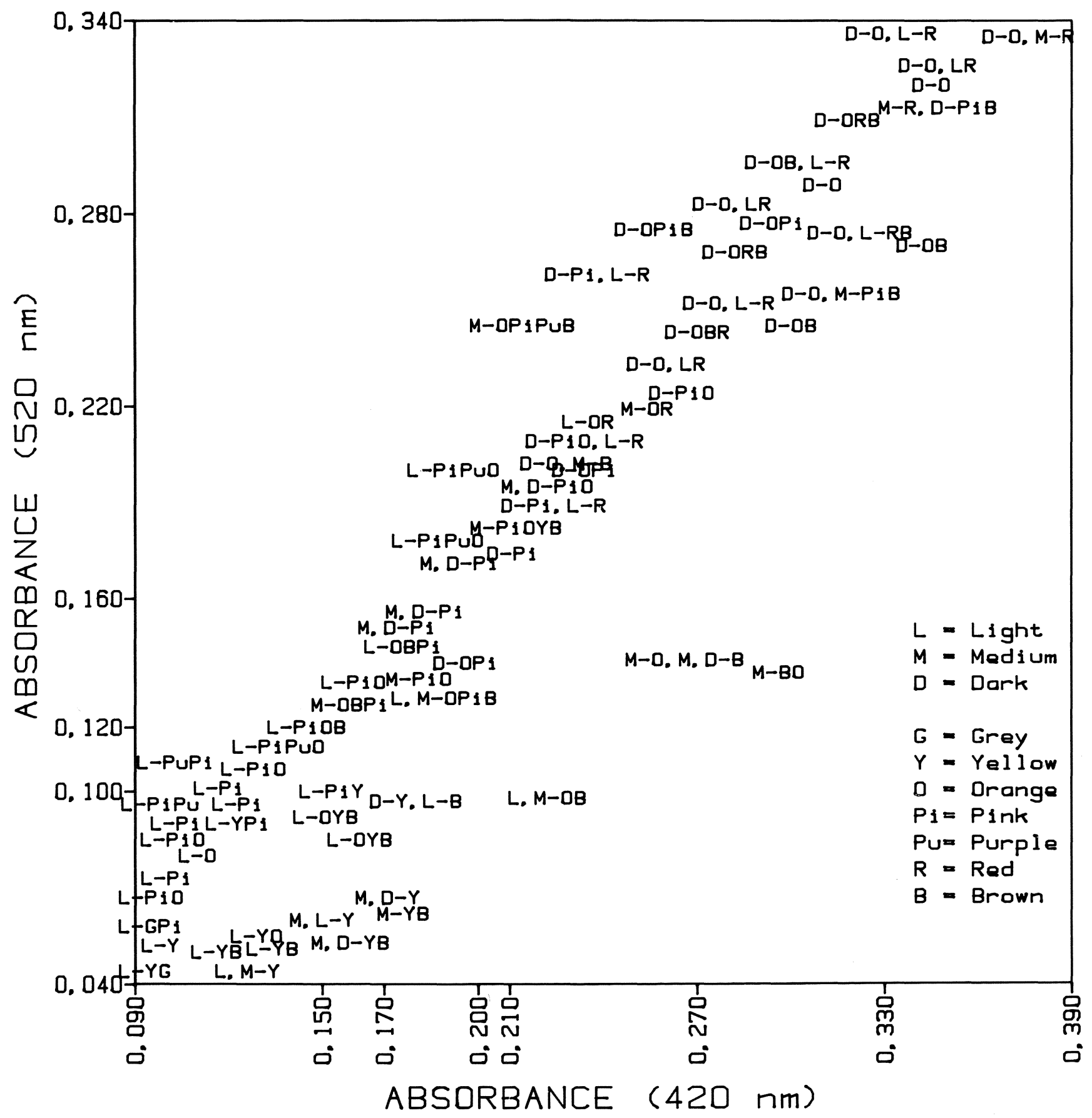

FIG. 2

Plot of blanc de noir visual colour against absorbance values at $420 \mathrm{~nm}$ and $520 \mathrm{~nm}$. 
although it could not be shown in the figure (due to overwriting). Although no definite colour areas could be demarcated, it is evident that similar visual colours (descriptions) tend to group together. This visual colour description, and the grouping of similar colours, is especially useful for studying colour changes during ageing and for the setting of colour preference limits for this type of wine.

\section{The effect of temperature on colour changes during ageing:}

The spectrophotometrically measured changes in absorbance at $420 \mathrm{~nm}$ and $520 \mathrm{~nm}$ for two of the wines during ageing at $0,10,20^{\circ} \mathrm{C}$ and $30^{\circ} \mathrm{C}$ are given in Fig's. 3 and 4 respectively. For both wines, at all temperatures tested, the absorbance increased rapidly during the first three months of ageing after which it remained relatively constant or increased at a slower rate. The increase in absorbance values at $420 \mathrm{~nm}$ (Fig. 3) is in accordance with the results of several previous workers (Simpson, 1982; Singleton, Trousdale \& Zaya, 1979). The increase in absorbance values at $520 \mathrm{~nm}$ (Fig. 4) is an interesting observation which cannot be explained at this stage. In red wines the absorbance values at $520 \mathrm{~nm}$ normally decrease during ageing (Sims \& Morris, 1984).

The observed effect of temperature on the colour changes during ageing was as expected, namely greater increases in absorbance values at the higher temperatures, particularly at $30^{\circ} \mathrm{C}$. The actual increases in absorbance readings were higher in the wines which initially had a more intense colour. Visual colour changes in four of the six studied wines during ageing at $10^{\circ} \mathrm{C}$ and $20^{\circ} \mathrm{C}$ are given in Table 2 . In general it is clear that pink wines became pink-orange to brown, while yellow wines tended to darken and become yellow-brown. Darker colours were observed at an earlier stage during ageing at the higher temperatures. The loss of the light pink colour in wines after two years' ageing at $20^{\circ} \mathrm{C}$ and $30^{\circ} \mathrm{C}$ (data not shown) confirms the importance of low

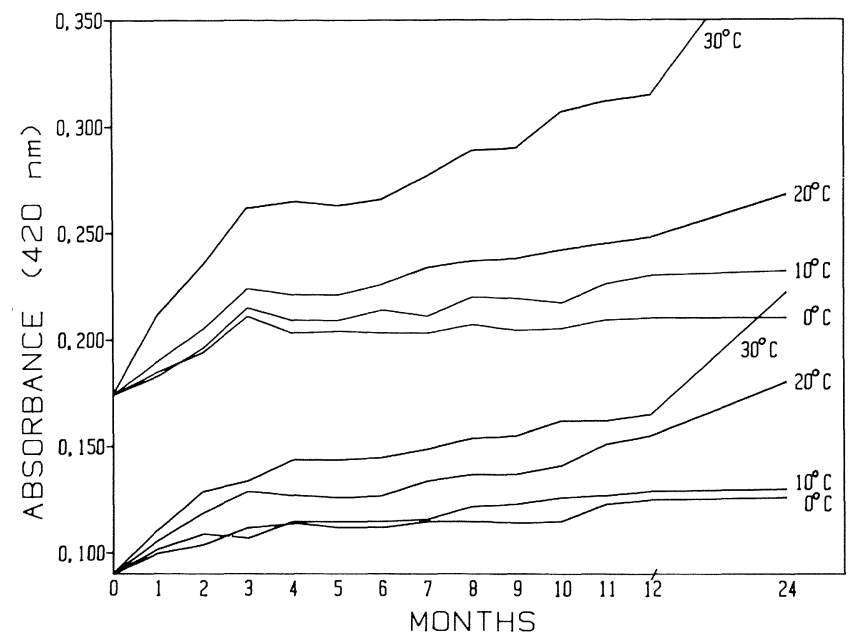

FIG. 3

Absorbance $(420 \mathrm{~nm})$ changes in two blanc de noir wines during ageing at different temperatures.

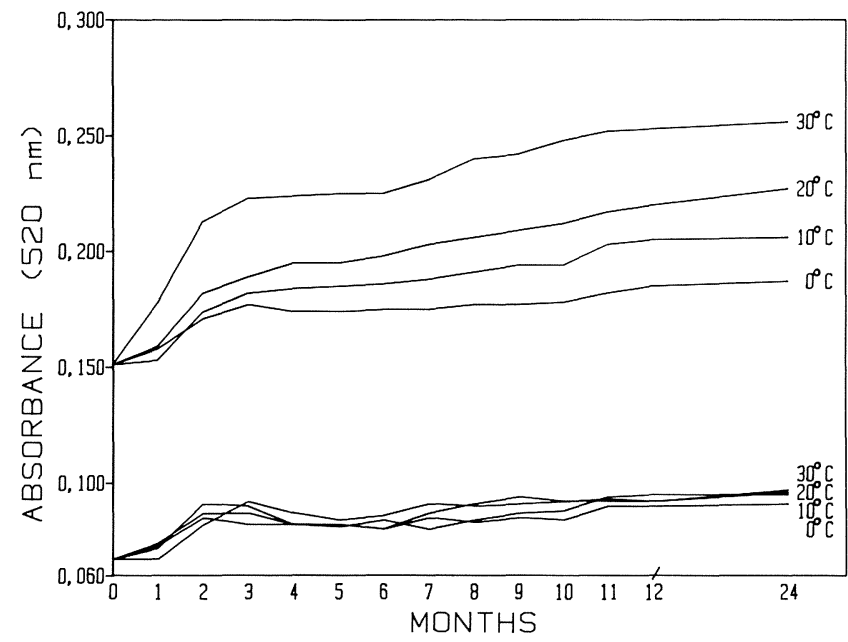

FIG. 4

Absorbance $(520 \mathrm{~nm})$ changes in two blanc de noir wines during ageing at different temperatures.

TABLE 2

Visual colour changes in four blanc de noir wines during ageing at two temperatures.

\begin{tabular}{|c|c|c|c|c|}
\hline $\begin{array}{l}\text { Initial } \\
\text { colour }\end{array}$ & $\begin{array}{l}\text { Ageing Tempe- } \\
\text { rature }\left({ }^{8} \mathrm{C}\right)\end{array}$ & After 3 months & After 12 months & After 24 months \\
\hline $\begin{array}{l}\text { Light yellow- } \\
\text { brown }\end{array}$ & $\begin{array}{l}10 \\
20\end{array}$ & $\begin{array}{l}\text { Light yellow-brown } \\
\text { Medium yellow }\end{array}$ & $\begin{array}{l}\text { Light to medium yellow } \\
\text { Medium to dark yellow, } \\
\text { light brown }\end{array}$ & $\begin{array}{l}\text { Light to medium yellow } \\
\text { Dark yellow-brown }\end{array}$ \\
\hline Light pink & $\begin{array}{l}10 \\
20\end{array}$ & $\begin{array}{l}\text { Light to medium pink } \\
\text { Light to medium pink, } \\
\text { light orange }\end{array}$ & $\begin{array}{l}\text { Light to medium pink } \\
\text { Medium pink-orange }\end{array}$ & $\begin{array}{l}\text { Light to medium pink- } \\
\text { orange } \\
\text { Medium orange }\end{array}$ \\
\hline $\begin{array}{l}\text { Light pink- } \\
\text { orange }\end{array}$ & $\begin{array}{l}10 \\
20\end{array}$ & $\begin{array}{l}\text { Light orange-pink } \\
\text { Light orange-pink }\end{array}$ & $\begin{array}{l}\text { Light to medium orange- } \\
\text { pink } \\
\text { Light orange, medium } \\
\text { yellow-brown }\end{array}$ & $\begin{array}{l}\text { Light to medium orange, } \\
\text { light brown } \\
\text { Dark yellow, light } \\
\text { brown }\end{array}$ \\
\hline $\begin{array}{l}\text { Medium to } \\
\text { dark pink, } \\
\text { light red }\end{array}$ & $\begin{array}{l}10 \\
20\end{array}$ & $\begin{array}{l}\text { Medium pink, light } \\
\text { orange } \\
\text { Dark pink, light orange- } \\
\text { red }\end{array}$ & $\begin{array}{l}\text { Medium pink, light } \\
\text { orange } \\
\text { Medium to dark orange }\end{array}$ & $\begin{array}{l}\text { Dark orange, medium } \\
\text { brown } \\
\text { Medium to dark orange- } \\
\text { brown }\end{array}$ \\
\hline
\end{tabular}


temperature storage to retain colour quality. After ageing for two years at $0^{\circ} \mathrm{C}$ (data not shown) and $10^{\circ} \mathrm{C}$, a pink colour could still be observed in these wines. The orange-brown coloration in the wines stored at high temperatures was associated with an oxidation type of colour, although the wines had no oxidation character on taste. It is, therefore, clear that blanc de noir wines could retain desirable colour characteristics for periods of up to two years if stored under ideal conditions.

Marais \& Pool (1980) pointed out that low temperature storage of white wines is beneficial for the retention of the typical young wine character over long periods of time. It is therefore clear that special atten- tion must be paid to the determination of the correct, and economically feasible, storage conditions for blanc de noir wines, in order to retain a young wine character as well as an acceptable colour.

\section{Colour standardization for blanc de noir wines:}

The visual acceptability/unacceptability rating of blanc de noir colour plotted against the two absorbance readings, is given in Fig. 5. In general it is clear that wines with visual colours, of which the absorbance readings at $420 \mathrm{~nm}$ and $520 \mathrm{~nm}$ exceed 0,200 and 0,160 respectively, are unacceptable as blanc de noir. Superimposing Fig's. 2 and 5 it can be seen that most of the colours at $A_{520}$ values of 0,160 are medium to dark pink,

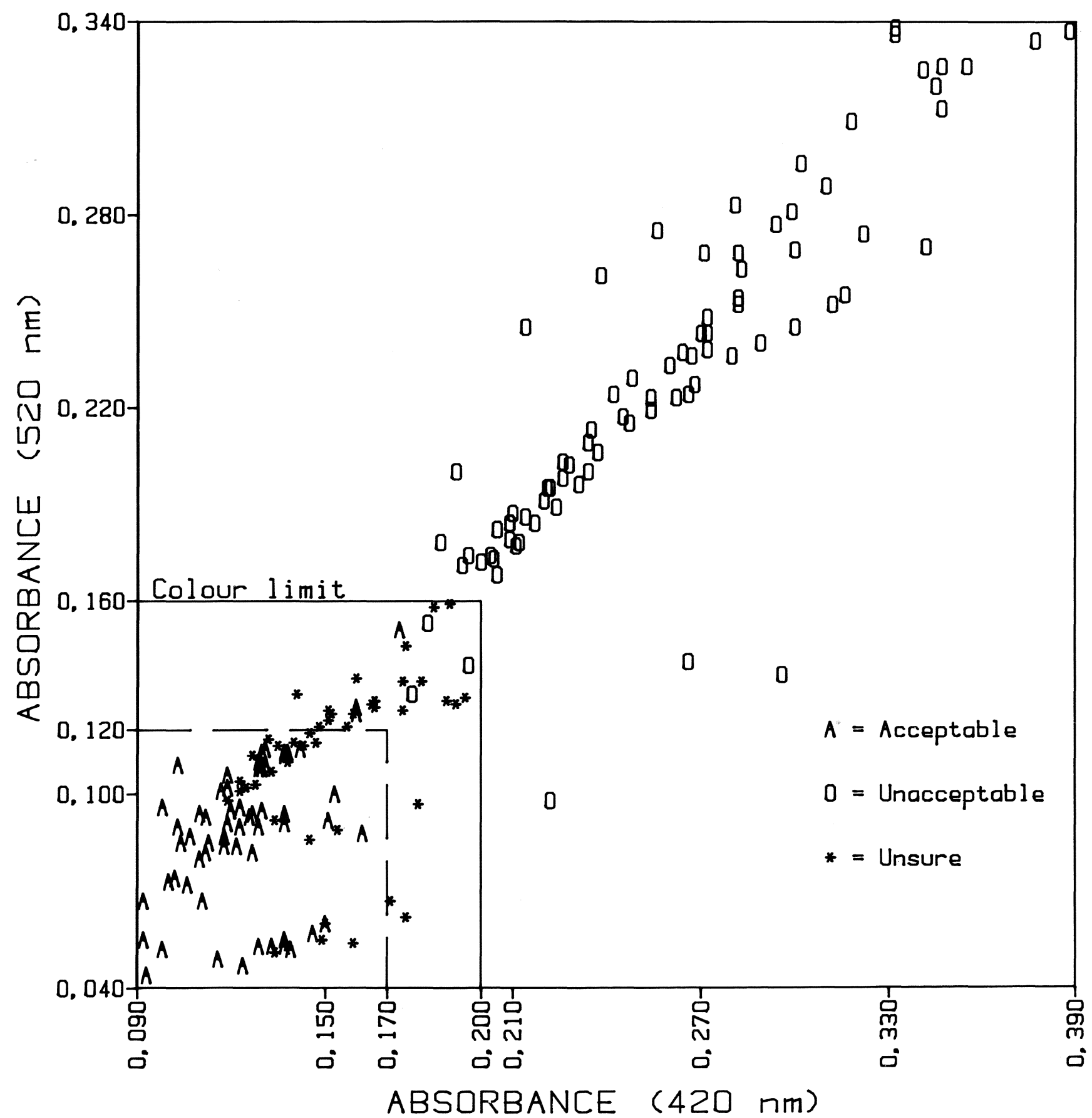

FIG. 5

Visual acceptability/unacceptability ratings of blanc de noir colour plotted against absorbance values at two wavelengths. 
while higher absorbance values $\left(\mathrm{A}_{520}>0,160\right)$ correspond to dark pink, light red and orange colours. Most of the judges commented on the necessity of restricting pink/red coloration in blanc de noir wines in order to separate this type of wine from rosé. Since absorbance readings at $520 \mathrm{~nm}$ are indications of red coloration, it is clear that an approximate $A_{520}$ value must be set. $A_{420}$ readings are, on the other hand, indications of yellow/ brown coloration, and can therefore be used to separate wines with too much yellowness/brownness.

From this study it is clear that the spectrophotometric colour of blanc de noir wines is generally susceptible to changes during ageing. The colour of a wine, which was initially acceptable may therefore become unacceptable within a short time. It was also found that the absorbance readings in wines with higher initial absorbance, tended to increase more than in wines with lower initial absorbance. Thus by accepting initial limits which are too high, increases in absorbance during ageing can result in visually unacceptable wines.

\section{Determination of a colour preference limit:}

The following colour limit is proposed to separate blanc de noir from other wine types: Absorbance measured in a $10 \mathrm{~mm}$ light path against a water reference, must not be more than 0,200 and 0,160 at $420 \mathrm{~nm}$ and $520 \mathrm{~nm}$ respectively. This limit clearly separates acceptable from unacceptable colours. Wines with colours of which the absorbance values exceed the proposed values are more suited for rosé and red wines. Most judges, however, preferred colours of which the absorbance values did not exceed 0,170 and 0,120 at $420 \mathrm{~nm}$ and $520 \mathrm{~nm}$ respectively, as indicated by the dotted line in Fig. 5. Colour limits must, however, make provision for possible changes as a result of ageing, and must be adjusted accordingly. The actual increases in absorbance values of wines 3 and 5 at the different temperatures are given in Table 3 . From these results it can be seen that the absorbance values of wine 3 still satisfied the proposed limit after two years of storage at $0^{\circ} \mathrm{C}$, $10^{\circ} \mathrm{C}$ and $20^{\circ} \mathrm{C}$, but exceeded the 0,200 limit $\left(\mathrm{A}_{420}\right)$ after one year of storage at $30^{\circ} \mathrm{C}$. The results for wine 5 indicate that storage resulted in increases in absorbance values to such an extent that it no longer fell within the confines of the proposed limit after two months of storage at $0^{\circ} \mathrm{C}, 10^{\circ} \mathrm{C}$ and $20^{\circ} \mathrm{C}$, as well as one month at $30^{\circ} \mathrm{C}$. The initial colour (medium to dark pink) of wine 5 was apparently too intense and already doubtful because only 10 of the 16 judges agreed on the acceptability.

The results indicate that wines with initial colours of which the absorbance values at $420 \mathrm{~nm}$ and $520 \mathrm{~nm}$ do not exceed 0,170 and 0,120 respectively, would still satisfy the confines of the proposed limit under normal storage conditions $\left(15-20^{\circ} \mathrm{C}\right)$ for at least two years. The proposed limit $\left(A_{420}<0,200 ; A_{520}<0,160\right)$ can therefore be imposed as an applicable limit for blanc de noir colours.

\section{SUMMARY AND CONCLUSIONS}

Blanc de noir wines with more intense colours are generally susceptible to colour changes during ageing, resulting in the overall loss of colour acceptability. This colour instability may severely limit the shelf-life of certain blanc de noir wines and may hinder the marketing of this product. It has been shown that high tempera-

TABLE 3

Absorbance changes in two blanc de noir wines during storage at different temperatures.

\begin{tabular}{|c|c|c|c|c|c|c|c|c|}
\hline \multirow{3}{*}{$\begin{array}{c}\text { Storage } \\
\text { time } \\
\text { (months) }\end{array}$} & \multicolumn{8}{|c|}{ Wine 3} \\
\hline & \multicolumn{4}{|c|}{ Absorbance $420 \mathrm{~nm}$} & \multicolumn{4}{|c|}{ Absorbance $520 \mathrm{~nm}$} \\
\hline & $0^{\circ} \mathrm{C}$ & $10^{\circ} \mathrm{C}$ & $20^{\circ} \mathrm{C}$ & $30^{\circ} \mathrm{C}$ & $0^{\circ} \mathrm{C}$ & $10^{\circ} \mathrm{C}$ & $20^{\circ} \mathrm{C}$ & $30^{\circ} \mathrm{C}$ \\
\hline 0 & 0,103 & 0,103 & 0,103 & 0,103 & 0,090 & 0,090 & 0,090 & 0,090 \\
\hline 1 & 0,112 & 0,112 & 0,122 & 0,123 & 0,093 & 0,091 & 0,099 & 0,096 \\
\hline 2 & 0,117 & 0,123 & 0,130 & 0,141 & 0,101 & 0,104 & 0,113 & 0,131 \\
\hline 3 & 0,119 & 0,133 & 0,142 & 0,151 & 0,106 & 0,110 & 0,114 & 0,126 \\
\hline 6 & 0,124 & 0,128 & 0,143 & 0,166 & 0,100 & 0,107 & 0,115 & 0,127 \\
\hline 12 & 0,128 & 0,137 & 0,158 & $\mathbf{0 , 2 0 1}$ & 0,105 & 0,111 & 0,125 & 0,136 \\
\hline 24 & 0,130 & 0,139 & 0,175 & 0,266 & 0,108 & 0,113 & 0,135 & 0,141 \\
\hline \multirow{3}{*}{$\begin{array}{c}\text { Storage } \\
\text { time } \\
\text { (months) }\end{array}$} & \multicolumn{8}{|c|}{ Wine 5} \\
\hline & \multicolumn{4}{|c|}{ Absorbance $420 \mathrm{~nm}$} & \multicolumn{4}{|c|}{ Absorbance $520 \mathrm{~nm}$} \\
\hline & $0^{\circ} \mathrm{C}$ & $10^{\circ} \mathrm{C}$ & $20^{\circ} \mathrm{C}$ & $30^{\circ} \mathrm{C}$ & $0^{\circ} \mathrm{C}$ & $10^{\circ} \mathrm{C}$ & $20^{\circ} \mathrm{C}$ & $30^{\circ} \mathrm{C}$ \\
\hline 0 & 0,174 & 0,174 & 0,174 & 0,174 & 0,151 & 0,151 & 0,151 & 0,151 \\
\hline 1 & 0,185 & 0,183 & 0,190 & $\mathbf{0 , 2 1 2}$ & 0,158 & 0,153 & 0,159 & $\mathbf{0 , 1 7 8}$ \\
\hline 2 & 0,194 & 0,196 & 0,205 & 0,235 & 0,171 & $\mathbf{0 , 1 7 4}$ & $\mathbf{0 , 1 8 2}$ & 0,213 \\
\hline 3 & 0,211 & $\mathbf{0 , 2 1 5}$ & 0,224 & 0,262 & 0,177 & 0,182 & 0,189 & 0,223 \\
\hline 6 & 0,203 & 0,214 & 0,226 & 0,266 & 0,175 & 0,186 & 0,198 & 0,224 \\
\hline 12 & 0,212 & 0,230 & 0,248 & 0,315 & 0,182 & 0,203 & 0,217 & 0,252 \\
\hline 24 & 0,210 & 0,228 & 0,268 & 0,421 & 0,187 & 0,202 & 0,227 & 0,256 \\
\hline
\end{tabular}

The bold values indicate the stage at which the absorbance values exceed the proposed limit. 
tures during ageing play an important role in this regard, especially temperatures above $20^{\circ} \mathrm{C}$ where colour changes occur rapidly and the visual colour may become unacceptable within a few months.

Although no large scale consumer preference studies have been made to indicate what specific colour (or colours) the public prefers for blanc de noir wine, some guidelines were obtained by using experienced judges. Certain colour preference limits are proposed for blanc de noir wines. A limit where the spectrophotometrically measured absorbance values at 420 and $520 \mathrm{~nm}$ do not exceed 0,200 and 0,160 respectively, was found to be the best way to separate acceptable from unacceptable colours. However, producers are advised to produce blanc de noir wines with initial colours that do not exceed 0,170 and 0,120 absorbance at $420 \mathrm{~nm}$ and 520 $\mathrm{nm}$ respectively to provide for colour changes during ageing. To ensure the retention of an acceptable colour after ageing, these wines must be stored at low temperatures and storage time should be kept as short as possible. However, winemakers are advised to determine whether or not it will be economically feasible to create ideal storage conditions for this wine type.

The results reported demonstrate the feasibility and desirability of absorbance determinations $\left(\mathrm{A}_{420}\right.$ and $A_{520}$ ) and visual descriptions, for evaluating the colour of blanc de noir wines. This method may be suitable for similar studies on other wine types and wine where all the samples have very similar spectral characteristics.

\section{LITERATURE CITED}

AMERINE, M.A. \& OUGH, C.S., 1975. Wine and must analysis. Wiley \& Sons, New York.

AMERINE, M.A., OUGH, C.S. \& BAILEY, C.B., 1959. Color values of California wines. Food Technol. 13, 170-175.

MARAIS, J. \& POOL, H.J., 1980. Effect of storage time and temperature on the volatile composition and quality of dry white table wines. Vitis 19, 151-164.

OUGH, C.S. \& AMERINE, M.A., 1967. Rosé wine color preference and preference stability by an experienced and an inexperienced panel. J. Food Sci. 32, 706-711.

PIRACCI, A., 1984. Determinazione computerizzata delle caratteristiche chromatiche dei vini bianchi. Riv. Vitic. Enol. 37, 139150 .

ROBINSON, W.B., BERTINO, J.J. \& WHITCOMBE, J.E., 1967. Objective measurement and specification of color in red wines. Am. J. Enol. Vitic. 17, 118-125.
SIMPSON, R.F., 1982. Factors affecting oxidative browning of white wine. Vitis 21, 233-239.

SIMS, C.A. \& MORRIS, J.R., 1984. Effects of pH, sulfur dioxide, storage time and temperature on the color and stability of Red Muscadine Grape wine. Am. J. Enol. Vitic. 35, 35-39.

SINGLETON, V.L., TROUSDALE, E. \& ZAYA, J., 1979. Oxidation of wines. 1. Young white wines periodically exposed to air. Am. J. Enol. Vitic. 30, 49-54.

TIMBERLAKE, C.R., 1981. Parameters of red wine quality. Food Technology in Australia 33, 139-144.

TROMP, A. \& VAN WYK, C.J., 1977. The influence of colour on the assessment of red wine quality. Proc. S. Afr. Soc. Enol. Vitic. 107-118.

WINKLER, A.J. \& AMERINE, M.A., 1938. Color in California wines. 1. Methods for measurement of color. Food Research 3, 429-438. 